\title{
Mewaspadai Pembajakan Operasi Perdamaian: Telaah Kritis Intervensi Asing dalam Konflik Libya
}

\author{
Nuruddin Al Akbar \\ Jurusan Politik dan Pemerintahan, Universitas Gadjah Mada
}

\begin{abstract}
This study seeks to explore the hidden challenges to the mission/operation of peace (peace operation/mission). Ideally, as envisioned by the perspective of liberal peace, humanitarian mission should be carried out purely on the basis of values of humanism in order to address the humanitarian crisis phenomenon. However, this assumption has weaknesses because it is ignorant of potential piracy against peace operations in which the latter are just cover for the implementation of the vested interests of the actors involved in the mission. Piracy against peace operations is essentially a new form of "civilizing mission", the strategy used by colonialist countries in order to give legitimacy to their rule in the colonies. The essence of the "civilizing mission" strategy is to show the invaders as a helper of the colonized countries. This study would like to explore how piracy against these peace operations occur in the context of Libya (2011). A number of foreign countries such as the United States are involved in peace operations in Libya, with the primary mission to implement a no-fly zone and protection of human security. This study includes a discussion of the vested interests behind the peace mission, the discourse used by the actors mission to wrap their vested interests as purely based on humanism, and the impact of of this strategy to the conduct of peace operations in general.
\end{abstract}

Keywords: Hijacking, Peace Operation/Mission, Liberal Peace, No-Fly Zone, Libya

\begin{abstract}
Abstrak
Studi ini berupaya mengeksplorasi tantangan terselubung terhadap konsepsi misi/operasi perdamaian (peace operation/mission). Secara ideal, sebagaimana dibayangkan oleh perspektif liberal peace, misi kemanusiaan dilaksanakan murni atas dasar nilai humanisme, guna mengatasi fenomena krisis kemanusiaan. Akan tetapi asumsi ini memiliki kelemahan karena abai terhadap potensi pembajakan terhadap operasi perdamaiandimana operasi perdamaian hanyalah kedok bagi terlaksananya kepentingan terselubung dari aktor yang terlibat dalam misi tersebut. Pembajakan terhadap operasi perdamaian pada hakekatnya merupakan bentuk baru dari "civilizing mission", yakni strategi yang dipakai sejumlah negara kolonial guna memberikan legitimasi bagi kekuasaan mereka di negeri jajahan. Intisari dari strategi "civilizing mission" ini adalah dengan cara menampakkan penjajah sebagai penolong negara jajahan tersebut. Studi ini ingin menelusuri bagaimana pembajakan terhadap operasi perdamaian ini terjadi dalam konteks Libya (2011). Sejumlah negara asing seperti AS terlibat dalam operasi perdamaian ke Libya, dengan misi utama untuk menerapkan no-fly zone dan perlindungan terhadap keamanan manusia. Studi ini meliputi pembahasan tentang kepentingan terselubung di balik misi perdamaian, wacana yang dipakai untuk membungkus kepentingan terselubung mereka seolah murni berdasarkan humanisme, dan dampak dari strategi ini terhadap operasi perdamaian secara umum.
\end{abstract}

Kata Kunci: Pembajakan, Operasi Perdamaian, Liberal Peace, No-Fly Zone, Libya 
Istilah operasi/misi perdamaian mungkin masih terasa asing pada sebagian besar benak masyarakat Indonesia. Namun berbeda ketika menyebut Kontingen Garuda atau KONGA, dimana istilah tersebut relatif dikenal oleh sebagian masyarakat. Istilah tersebut merujuk pada nama pasukan khusus Indonesia yang diterjunkan dalam operasi pemeliharaan perdamaian (peacekeeping operation) di luar negeri. Nama Garuda sendiri diambil dari lambang negara Indonesia yang berlambangkan burung garuda.

Tercatat Kontingen Garuda ini telah dikirim ke berbagai negara sejak pertama kali diresmikan pada tahun 1957. Mesir tercatat sebagai wilayah pertama penerjunan Kontingen Garuda. Misi Kontingen Garudabersama dengan pasukan dari negara lain-bertugas menjadi penengah dalam konflik yang melibatkan Mesir di satu sisi dan Israel, Inggris, dan Perancis di sisi yang lain. Konflik kedua belah pihak tersebut dipicu kebijakan Mesir untuk melakukan nasionalisasi terusan Suez (Headquarters of the Armed Forces of the Republic of Indonesia, 1995: 286). Langkah nasionalisasi terusan Suez dinilai Inggris, Perancis, dan Israel sebagai langkah yang membahayakan kepentingan mereka di kawasan tersebut.

Pasca menunaikan tugasnya di Mesir, tercatat Indonesia kembali mengirimkan tentaranya ke berbagai wilayah lain yang mengalami konflik, seperti Somalia, Bosnia, Sudan, dan Lebanon. Sepak terjang Indonesia terbilang aktif, terbukti sejak tahun 1957 (Mesir) hingga tahun 2009 Indonesia telah mengirimkan pasukannya ke luar negeri di bawah payung operasi pemeliharaan perdamaian sebanyak 65 kali (Warta Akrab, 2009: 74).

Sepak terjang tentara Indonesia dalam operasi pemeliharaan perdamaian sejatinya menunjukkan makna penting dari eksistensi sebuah operasi perdamaian. Berbeda dengan tugas militer konvensional pada umumnya yang terkait dengan penghancuran dan korban jiwa, tugas militer dalam misi perdamaian justru mengakhiri konflik dan menciptakan perdamaian dunia. Visi humanis inilah yang tergambar dengan jelas dari pernyataan Javier Perez de Cuellar di tahun
1988 saat ia menduduki jabatan Sekjen PBB. Menurut Cuellar, operasi perdamaian merupakan tonggak baru sejarah manusia dimana meskipun menempatkan militer sebagai kunci operasi, namun dengan tujuan yang berbeda dengan maksud konvensional didirikannya militer, yakni bukan untuk mendominasi, bukan memulai perang, dan bukan melayani kepentingan kelompok tertentu (Renner, 1995: 327)

Pernyataan Ceullar tersebut memberikan penegasan tentang bayangan ideal eksistensi sebuah misi perdamaian. Bahwasanya militer yang datang ke sebuah negara yang sedang mengalami masalah konflik, baik internal (seperti perang saudara) atau eksternal (perang dengan negara lain), memiliki tugas mulia guna menghentikan konflik yang melanda negara tersebut.

Imaji militer sebagai aktor resolusi konflik salah satunya tergambar dari cara tentara Indonesia menengahi konflik saat mereka bertugas di Lebanon. Dalam sebuah kesempatan, terjadi riak-riak konflik antara anak-anak Lebanon dengan tentara Israel. Anak-anak Lebanon yang marah dengan invasi militer Israel secara spontan melempari tentara Israel dengan batu. Tentara Indonesia yang melihat peristiwa tersebut segera menghampiri sang anak, berusaha memberikan nasehat pada mereka secara halus agar menghentikan aksinya (Yulianto, 2010: 18-19).

Aksi yang dilakukan tentara Indonesia berhasil mencegah aksi spontan tersebut berubah menjadi konflik berdarah, karena tentara Israel yang mereka lempari tersebut bersenjata lengkap dan mengendarai kendaraan tempur. Bisa dibayangkan jika tentara Israel membalas serangan mereka dengan senjata lengkap yang mereka bawa. Dalam sekejap anak-anak tersebut dapat tewas seketika dan memicu serangan balasan dari penduduk Lebanon. Nampak jelas bagaimana gambaran ideal tentara yang melakukan misi perdamian yang berkarakter santun, tidak berpihak, tidak menggunakan kekerasan, dan bertindak dengan dasar untuk mencegah konflik dan mempertahankan perdamaian. 
Bayangan ideal tersebut semakin nampak ketika mencermati sepak terjang militer dalam sejumlah kegiatan murni non perang, seperti keterlibatan militer berbagai negara dalam membantu penanganan bencana alam di sebuah wilayah. Indonesia sendiri pernah mengalami sejarah mendapatkan bantuan militer asing untuk penanggulangan bencana alam tsunami di Aceh pada tahun 2004. Diperkirakan dalam operasi humanitarian tersebut, AS menerjunkan sekitar 14 ribu tentaranya termasuk mengerahkan 57 helikopternya. Selain AS tercatat negara lain yang mengirimkan pasukannya seperti Jepang, Pakistan, Autsralia, dan Singapura (BBC Indonesia, 2005).

Selama melakukan tugasnya, tentara asing di Aceh tercatat melakukan berbagai aksi kemanusiaan. Tentara AS misalnya, melakukan penyelamatan pada korban Tsunami untuk dibawa ke tempat yang aman. Selain misi penyelamatan korban, tercatat tentara AS juga memberikan bantuan makanan dan minuman kepada para korban, sekaligus melakukan pengobatan pada para korban yang memerlukannya (US Departement of Defence, no date). Sebuah bayangan yang mungkin bertolak belakang dengan gambaran AS selama ini, dimana militernya sibuk menginvasi berbagai negara di dunia.

Bayangan ideal tentang keterlibatan militer dalam operasi perdamaian atau misi lain yang sifatnya humaniter tersebut tentunya tidak keliru, namun yang menjadi pertanyaan apakah hal tersebut berlaku untuk setiap keadaan? Pertanyaan kritis inilah yang seharusnya diajukan agar tidak mudah menerima asumsi normatif akan operasi perdamaian. Terlebih lagi jika mencermati ruang lingkup operasi perdamaian. Sebagaimana ditegaskan di awal, misi tentara Indonesia merupakan misi pemeliharaan perdamaian (peacekeeping mission/ operation). Padahal operasi perdamaian tidak hanya mencakup pemeliharaan perdamaian saja, tetapi lebih luas.

Luasnya ruang lingkup misi perdamaian terjadi karena, sebagaimana ditegaskan Alex J. Bellamy dan Paul Williams
(2010:14), hingga saat ini tidak ada kesepakan mengenai apa definisi operasi perdamaian. Bahkan dalam level organisasi internasional PBB yang seringkali disoninimkan sebagai lembaga yang bertanggung jawab membentuk misi/operasi perdamaian, faktanya tidak ada keterangan yang jelas dalam piagam PBB mengenai definisi operasi perdamaian (Bellarmy \& Williams, 2010:14).

Meskipun tidak ada definisi yang jelas tentang operasi perdamaian, akan tetapi berdasar telaah pada dokumen yang dikeluarkan UN Department for Peacekeeping Operations (DPKO), setidaknya ada beberapa kategori penting kegiatan yang dapat dimasukkan ke dalam ruang lingkup operasi perdamaian. Kegiatan tersebut ialah: 1) conflict prevention, yakni terkait dengan pencegahan konflik baik secara struktural atau diplomatik, 2) peacemaking, yakni upaya mendudukkan pihak yang bertikai agar mencapai sebuah kesepakatan melalui strategi diplomasi, 3) peacekeeping, yakni terkait penggunaan kekuatan militer, dan non militer (polisi dan sipil) guna membangun fondasi perdamaian yang berkelanjutan di sebuah negara 4) peace enforcement, terkait penggunaan kekuatan militer dan langkah lain yang diperlukan untuk memberlakukan keinginan Dewan Keamanan PBB, dan 5) peacebuilding, terkait penggunaaan berbagai kekuatan dan strategi yang dibutuhkan untuk mengurangi resiko terjadinya konflik di kemudian hari pasca terwujudnya perdamaian (Bellarmy \& Williams, 2010:15).

Merujuk pada telaah dokumen UNDPKO diatas sejatinya semakin menguatkan perlunya cara pandang yang non konvensional dalam memahami operasi perdamaian. Karena sangat jelas bagaimana luasnya ruang lingkup operasi tersebut, campur tangan asing yang sangat besar dalam mengatasi problem dalam suatu negara menjadi sangat mungkin.

Tidak dapat dipungkiri bahwa luput atau kurangnya kritik terhadap eksistensi operasi perdamaian ini juga dipengaruhi oleh perspektif yang banyak tersebar di kalangan akademisi yakni liberal peace (Bellarmy \& Williams, 2010:23). Perspektif liberal peace sendiri membayangkan adanya nalar kebaikan, kebajikan, atau suka menolong di 
balik eksistensi sebuah operasi perdamaian. Menurut perspektif ini negara-negara di dunia menginginkan adanya kedamaian dan stabilitas pada tatanan global. Ketika terjadi konflik atau kekerasan pada sebuah negara, maka dengan segera menimbulkan reaksi dari negara-negara lain, khususnya negara demokrasi. Negara tersebut terpanggil karena ada "teriakan" penderitaan dari negara yang terkena konflik. Dengan segera negara-negara tersebut akan mengambil langkah "tanggap darurat" untuk mengatasi agar konflik atau kekerasan yang terjadi dapat dikendalikan. Tindakan "tanggap darurat" tersebut juga memiliki misi utama menolong kalangan tak berdaya yang terjebak dalam konflik. Ketika konflik berhasil dipadamkan melalui campur tangan negara-negara lain, maka tatanan global yang damai dan stabil dapat kembali terjaga (Urlacher, no date: 2-3).

Berdasar penjelasan Urlacher tersebut, jelas tergambar bagaimana adopsi perspektif liberal peace jelas tidak akan mendorong sikap kritis terhadap misi perdamaian karena sudah terlanjur memandangnya sebagai hal yang mulia. Negara yang melakukan atau terlibat dalam operasi perdamaian diasumsikan tergerak nuraninya terhadap rintihan penderitaan kalangan tidak berdaya dalam sebuah negara yang dilanda konflik. Bertolak dari rasa iba tersebut, negara yang terlibat dalam misi perdamaian segera merespon dengan aksi nyata guna menghentikan konflik dan mengembalikan kedamaian di negara tersebut.

Tentu tidak dapat dipungkiri terdapat potensi ketulusan, humanisme, dan peri kemanusiaan yang melatarbelakangi sebuah misi perdamaian sebagaimana dibayangkan oleh perspektif liberal peace. Namun, yang menjadi masalah apakah hal itu selalu terjadi dalam setiap keadaan? Temuan Tania Gosh (2010) membantah asumsi tersebut. Dalam penelitiannya, negara Afrika yang berpartisipasi dalam misi perdamaian ternyata didorong persoalan material. Material yang dimaksud ialah reward yang diperoleh ketika mengirimkan tentaranya dalam operasi perdamaian. Sebagai contoh, setiap tentara yang terlibat dalam misi perdamaian mendapatkan jatah gaji perbulan sebesar US $\$ 1,000.00$. Dana tersebut tidak diberikan kepada prajurit secara individual, tetapi pada negara yang mengirimkan pasukannya. Tentunya bagi negara Afrika yang banyak diantaranya tergolong miskin, kucuran dana tersebut menjadi daya tarik tersendiri.

Temuan Gosh tersebut dikuatkan dengan temuan Matthew Ross. Menurut Ross (2011,: 63-64), pengiriman pasukan perdamaian Afrika menguntungkan bagi pemerintah yang mengirimkan prajuritnya. Pemerintah negara tersebut dapat memberikan gaji lebih kepada sang prajurit karena adanya suntikan dana asing sebagai kompensasi keterlibatan tentara negara tersebut dalam misi perdamaian.

Dalam konteks Afrika, peningkatan gaji tersebut amat penting untuk meneguhkan kesetiaan tentara pada pemerintah. Terlebih lagi dengan keterlibatan negara dalam sebuah misi perdamaian ternyata juga membawa keuntungan material lain, yakni dianggap sebagai negara yang "patuh" pada norma internasional, sehingga memudahkan negara tersebut mendapatkan bantuan keuangan internasional atau Foreign Direct Investment (FDI) (Ross, 2011: 63-64)

Temuan Gosh dan Ross menunjukkan jelas adanya kepentingan di balik misi perdamaian. Bukan karena tangisan penderitaan rakyat yang terkena konflik atau sikap suka menolong yang menjadi motivasi sebagian negara Afrika yang mengirim pasukan perdamaiannya, melainkan materi dan kepentingan nasional negara tersebut.

Temuan Gosh dan Ross menunjukkan bahwa dalam konteks negara Afrika saja ternyata bisa memiliki niat terselubung di balik operasi perdamaian, lalu bagaimana dengan negara-negara maju yang notabene lebih memiliki kepentingan terhadap negara dunia ketiga yang serigkali dilanda konflik dan kekerasan? Apakah mereka melakukan misi kemanusiaan hanya karena dorongan humanisme? Sangat sulit untuk mengatakan dorongan humanisme yang mendasari misi perdamaian mereka dalam setiap kesempatan.

Tulisan ini berupaya untuk menyibak upaya pembajakan misi kemanusiaan, 
khususnya yang dilakukan oleh negara-negara maju guna merealisasikan kepentingan mereka sendiri. Fokus pada tulisan ini sendiri ialah pada konflik Libya yang sempat menyita perhatian dunia Internasional. Konflik Libya dianggap sebagai titik tolak kepedulian masyarakat internasional (melalui PBB) untuk memastikan keamanan warga negara Libya dari ancaman kekejaman massal (mass atrocities) yang dilakukan oleh rezim Gaddafi (Schütte,2011: 2). Telaah pada tulisan ini mencakup kepentingan di balik keterlibatan negara maju tersebut, strategi yang dilakukan negara tersebut agar tindakan yang dilakukan seolah murni misi perdamaian, dan dampak dari kepentingan terselubung terhadap berjalannya misi perdamaian semu tersebut.

\section{Kerangka Memahami Pembajakan Operasi Perdamaian}

Guna memahami nalar dibalik keterlibatan negara maju di dalam sebuah konflik dan kekerasan yang terjadi di sebuah negara (terkhusus negara dunia ketiga) tesis Edward Said mengenai kolonialisme dan imperialisme dapat menjadi salah satu rujukan utama. Menurut Said (1994: 9) ada perbedaan mendasar antara kolonialisme dan imperialisme. Kolonialisme terkait dengan persoalan pendirian pemukiman (settlement) di wilayah yang jauh, seperti yang dilakukan Belanda ketika menduduki Indonesia. Sementara imperialisme terkait dengan praktek yang dilakukan untuk mendirikan atau menjaga kelangsungan sebuah imperium (empire).

Imperium sendiri didefinisikan Said (1994: 9) sebagai sebuah relasi yang memastikan penguasaan kedaulatan politik sebuah entitas politik (political society) oleh sebuah negara. Relasi ini dipertahankan dengan berbagai cara, baik dengan penggunaan kekuatan (force) ataupun strategi lain yang efektif, mencakup bidang ekonomi, politik, sosial, budaya.

Pemaparan Said tersebut menunjukkan bahwa imperialisme memiliki cakupan lebih luas dari kolonialisme Bahkan Said sendiri (1994: 9) memasukkan kolonialisme sebagai sebuah konsekuensi dari imperialisme. Oleh karena itu jelas dari pemaparan Said, bahwa negara kolonialis yang telah mengakhiri pendudukannya secara fisik pada negara jajahannya sebenarnya masih berupaya membangun relasi yang memungkinkan cengkramannya atas negara yang pernah dijajahnya tersebut.

Said (1993:2-3) memberi contoh menarik ketika menjelaskan bekerjanya imperialisme di India pada saat Inggris secara fisik masih menduduki wilayah tersebut. Selain berbekal kekuatan militer (kolonialisme), Inggris juga melakukan penyebaran wacana yang intinya memberikan kesan bahwa India tidak akan hadir atau tidak memiliki eksistensi jika tidak dikuasai Inggris. Wacana pro Inggris tersebut bahkan termanifestasi dalam novel, yang menandakan kuatnya pewacanaan tersebut hingga karya-karya yang sifatnya fiktif ikut terwarnai oleh kepentingan kolonialisme. Penjelasan Said tersebut memberikan penegasan bahwa cara-cara non fisik juga digunakan untuk memastikan India tetap berada di bawah kontrol Inggris. Tentunya strategi non fisik tersebut masih berpotensi untuk digunakan oleh Inggris atau negara kolonialis lain untuk terus menancapkan pengaruhnya di negara bekas jajahan karena cenderung terselubung.

Strategi semacam itulah yang secara umum dapat dipakai oleh negara-neegara maju di dunia secara umum untuk mengokohkan pengaruhnya di berbagai negara lain di tengah struktur internasional yang sudah jauh berbeda dengan zaman kolonial dahulu. Penggunaan kekuatan fisik secara murni oleh sebuah negara maju terhadap wilayah lain, sebagaimana yang lazim dilakukan di era kolonial, dengan segera akan membuat citra negara maju tersebut tercoreng di dalam pergaulan internasional. Bahkan tidak menutup kemungkinan, negara tersebut akan mendapatkan resistensi keras dari berbagai pihak sehingga sulit untuk mempertahankan kekuasaanya di wilayah tersebut.

Jika Said memberikan contoh strategi kuasa dengan penyebaran wacana yang salah satunya termanifestasi dalam novel, maka kuasa terselubung sejatinya juga dapat menyebar melalui ilmu pengetahuan. Poin 
penting dari ilmu pengetahuan ialah adanya kepercayaan meluas bahwa ilmu pengetahuan pasti netral dan bebas nilai, sehingga ketika kekuasaan dapat merasuk, menunggangi, atau membajak ilmu pengetahuan, maka kekuasaan tersebut akan mendapat jaminan stempel "ilmiah". Stempel "ilmiah" tersebut akan memudahkan penerimaan publik terhadap wacana tertentu yang sejatinya berisikan kuasa terselubung.

Contoh penting dari keberadaan kuasa yang menunggangi pengetahuan dapat ditemukan pada konsep governance. Governance secara singkat merujuk pada proses pengambilan keputusan (decision making) (UN ESCAP, no date: 1). Akan tetapi istilah ini kemudian seringkali dipakai untuk melabeli bagaimana pengambilan keputusan terkait kepentingan publik dalam lingkup sebuah negara. Governance sendiri biasanya dibagi berdasarkan karakteristiknya, yakni bad governance dan good governance. Penggunaan kata bad dan good memberikan konsekuensi penting bagi sebuah negara, karena ketika mendapatkan label bad, mana jangan berharap untuk mendapatkan berbagai bantuan internasional (UNESCAP, no date: 1).

Adanya implikasi yang diberikan kepada bad governance tentunya memicu sebuah negara untuk berlomba menerapkan good governence. Poin penting dari good governance sendiri ialah adanya sinergi antar aktor dalam proses pembuatan sebuah kebijakan publik. Secara garis besar, terdapat dua aktor tambahan selain negara-yang secara tradisional berwenang membuat suatu kebijakan-yakni yakni pasar dan civil society.

Tidak bisa dipungkiri good governence membuka peluang bagi masyarakat untuk turut serta dalam menentukan kebijakan sehingga dapat mendesakkan agenda yang diangap penting oleh mereka. Akan tetapi konsepsi good governance juga menyimpan peluang untuk "dibajak" sehingga bukannya menguntungkan rakyat dalam sebuah negara justru merugikannya.

Fenomena inilah yang terjadi di Zambia, sebuah negara berkembang yang terletak di benua Afrika. Governance menjadi alat bagi IMF dan World Bank untuk memaksa Zambia melakukan perubahan dramatis terkait dengan kebijakan publiknya. Sebagaimana dibahas di awal, pasar adalah aktor penting non-negara yang harus dilibatkan. Disinilah IMF dan World Bank menemukan celah untuk mengintervensi Zambia dengan menyatakan bahwa dibutuhkan lingkungan yang kondusif agar pasar dapat tumbuh di Zambia. Lingkungan kondusif yang dimaksud ialah penghapusan pembatasan impor, penghapusan subsidi negara terhadap makanan pokok, pupuk, dan komoditas lainnya (Abrahamsen, 2000: 143).

Dampak dari perubahan yang dilakukan pemerintah Zambia ternyata menghasilkan kekacauan di level masyarakat. Harga makanan yang melambung menyebabkan merebaknya penjarahan di wilayah perkotaan yang dilakukan orangorang miskin (Abrahamsen, 2000: 143). Naiknya harga juga mengakibatkan efek domino negatif lain seperti terjadinya PHK massal pada berbagai industri yang ada di Zambia. Tercatat di Industri petambangan saja, lebih dari 4 ribu orang terkena PHK. Kebjakan PHK tersebut akhirnya merembet kepada terjadinya berbagai kerusuhan industrial di Zambia pada tahun 1980an (Abrahamsen, 2000: 144).

Kisah Zambia di atas menyiratkan bahwa dengan memanfaatkan celah ilmu pengetahuan (dalam hal ini konsepsi governance), intervensi IMF dan World Bank dapat dilaksanakan pada Zambia. Jika IMF dan World Bank menggunakan paksaan pada Zambia untuk mengubah sistem ekonominya, tentunya akan memicu resistensi luas dari rakyat dan pemerintah negara tersebut. Namun berbekal konsepsi governance yang mensyaratkan hadirnya pasar sebagai aktor penting aktor non-negara, maka IMF dan World Bank dapat hadir ke dalam negara tersebut secara terhormat. Tercatat IMF dan World Bank bahkan dipercaya oleh Zambia untuk memberikan "panduan" bagaimana menumbuhkan pasar yang kuat di negara tersebut dengan melakukan liberalisasi ekonomi.

Terbukti penyebarluasan gagasan governance dalam pergaulan internasional membuat negara semacam Zambia secara sukarela menyesuaikan diri dengan ide 
tersebut. Tentu saja tindakan Zambia tersebut didorong rasa percaya terhadap konsepsi governance yang dianggap netral, nirkekuasaan, bahkan justru berguna untuk membenahi negara semacam Zambia untuk keluar dari jerat "bad governace".

Penggunaan pengetahuan sebagaimana terjadi dalam kasus governence itulah yang sejatinya juga terjadi pada kasus operasi perdamaian. Sebagaimana ditegaskan oleh Bellamy dan Williams (2010:14) hingga saat ini tidak ada kesepakan mengenai apa definisi operasi perdamaian. Ketidakjelasan definisi operasi perdamaian salah satunya berbuah pada tiadanya kesepakatan siapa pihak yang berhak melakukan operasi perdamaian. Walaupun hingga saat ini PBB masih dianggap sebagai pihak yang paling kredibel dalam menyelenggarakan operasi perdamaian, faktanya sejumlah negara atau kelompok negara hingga saat ini memiliki fungsi menyelenggarakan operasi perdamaian pula.

Contoh nyata dari kelompok negara yang memiliki fungsi ini ialah North Atlantic Treaty Organization (NATO). NATO merupakan warisan perang dingin saat terjadi konflik antara AS dan Uni Soviet guna memperebutkan dominasinya pada negaranegara dunia. AS membentuk NATO untuk menghadapi ancaman Uni Soviet yang dianggap ekspansif dan mengancam keselamatan negara-negara eropa pro AS. Secara khusus pendirian NATO merupakan respon dari eksistensi pakta warsawa, sebuah pakta pertahanan yang dibentuk oleh Soviet di wilayah Eropa Timur.

Runtuhnya Uni Soviet yang menandai berakhirnya perang dingin membuat NATO berbenah dalam menyikapi perubahan geopolitik global. Salah satu pembenahan diri NATO ialah melalui keterlibatannya dalam sejumlah operasi perdamaian. NATO memiliki istilah sendiri untuk menyebut operasi perdamaian yang dijalankannya yakni peace support operation.

NATO tercatat melakukan operasi perdamaian pertama di wilayah Yugasolavia untuk menghentikan perang saudara yang terjadi antara negara pecahan Yugoslavia tersebut. Perang di wilayah Yugoslavia sendiri dapat ditelusuri di tahun 1990-an dimana terjadi pemilihan umum di wilayah negara bagian Bosnia Herzegovina. Pemilihan umum di Bosnia Herzegovina sendiri menghasilkan keputusan membentuk pemerintahan koalisi Muslim, Serbia, dan Kroasia di bawah kepemimpinan presiden Izetbegovic. BosniaHerzegovina juga menyatakan keluar dari Yugoslavia dan memproklamasikan kemerdekaannya sebagai negara berdaulat. Deklarasi tersebut ditanggapi keras oleh minoritas Serbia dan Kroasia (di Bosnia) yang menginginkan mereka bergabung ke negara Serbia dan Kroasia, bukan mendirikan negara sendiri. Reaksi keras tersebut akhirnya menghasilkan perang saudara. Minoritas Serbia dan Kroasia dibantu oleh negara Serbia dan Kroasia melawan Muslim Bosnia. PBB sendiri menerjunkan pasukan perdamian yang disebut UN Protection Force (UNPROFOR) (Jackson, 1997: 13).

NATO menunjukkan eksistensinya sebagai kekuatan baru yang berbeda dengan masa Perang Dingin dengan turut serta masuk dalam misi perdamaian di Bosnia. Tercatat NATO membentuk misi khusus bernama NATO-led Implementation Force (IFOR) di tahun 1995 dan satu tahun berikutnya menggantinya dengan misi khusus bernama NATO-led Stabilisation Force (SFOR) (NATO, 2012). NATO memiliki keleluasaan bertindak karena dilegitimasi dengan UN Security Council Resolution (UNSCR) 1031 yang disahkan 15 Desember 1995. UNSCR memberikan mandat bagi NATO untuk memelihara perdamaian (peacekeeping) dan jika diperlukan, memastikan terjadinya perdamaian. Izin untuk "memastikan perdamaian" memberikan konsekuensi diberikannya izin bagi NATO untuk menggunakan berbagai cara yang dibutuhkan untuk mencapai keadaan tersebut, termasuk dengan kekuatan militer (NATO, 2012).

Apabila digolongkan dalam kategori UN Department for Peacekeeping Operations (DPKO), maka misi NATO termasuk dalam kategori peace enforcement. Misi NATO sebagai peace enforcement memungkinkan ia untuk melakukan segala langkah yang diperlukan, termasuk langkah militer untuk memastikan perdamaian di Bosnia. 
Misi NATO di Bosnia menunjukkan bahwa aktor non-PBB ternyata memiliki keleluasaan untuk bertindak dalam sebuah negara yang berdaulat ketika terjadi konflik. Aksi NATO semakin terlegitimasi dengan munculnya resolusi PBB yang memberikan keleluasaan gerak NATO di Bosnia.

Kasus NATO memang tidak menunjukkan NATO membajak operasi perdamaian di Bosnia, karena sebagaimana ditegaskan di awal, Bosnia adalah misi pertama NATO sebagai tentara perdamaian. Sehingga jikalau ada kepentingan di balik misi NATO yang dapat diidentifikasi, lebih kepada pengakuan sebagai kekuatan perdamaian, bukan lagi perang seperi di zaman Perang Dingin.

Kasus NATO memberikan penegasan penting bahwa aktor non PBB juga dapat secara independen melakukan operasi perdamaian. Keterlibatan NATO sendiri tidak dapat dilepaskan untuk mengubah citra dirinya menjadi lebih positif di era pasca Perang Dingin. Tentu menjadi sangat potensial bagi negara maju lain untuk memanfaatkan peluang independensi pembentukan misi perdamian tersebut untuk merealisasikan berbagai kepentingan terselubungnya sebagaimana terjadi dalam konteks Libya.

\section{Pembajakan Operasi Perdamaian di Libya}

Membicarakan pembajakan operasi perdamaian di Libya tidaklah lengkap tanpa memahami bagaimana konflik di Libya terjadi. Konflik di Libya sendiri tidak bisa dilepaskan dari perkembangan yang terjadi di wilayah Timur Tengah. Saat itu, terjadi fenomena yang disebut sebagai Arab Spring (Musim Semi Arab) yang memiliki konotasi pergantian rezim otoriter menuju demokrasi. Peristiwa pertama yang menadai munculnya Arab Sping ialah aksi demonstrasi yang terjadi di Tunisia di tahun 2010.

Aksi demonstrasi yang merebak dari masyarakat pada awalnya menuntut perbaikan ekonomi masyarakat yang buruk di masa pemerintahan Presiden Ben Ali. Akan tetapi sebuah peristiwa mengejutkan menjadi titik balik demonstrasi di Tunisia, dimana seorang bernama Buazizi melakukan aksi bakar diri di depan gedung pemerintahan. Buzaizi sendiri merupakan seorang pedagang sayuran yang mengalami perlakuan buruk oleh aparat keamanan. Dagangannya diambil paksa, ia dipukuli, dan dagangannya tersebut tidak dikembalikan oleh aparat keamanan pada dirinya (The New York Times, 2011a). Putus asa dengan kondisinya, ia memilih melakukan protes dengan cara membakar dirinya. Masyarakat yang simpatik dengan aksi Buazizi mengintensifkan demontsrasi dengan slogan baru yang menutut mundurnya Ben Ali. Akhirnya pada Januari 2014, Ben Ali memilih meinggalkan negara tersebut membawa serta sejumlah anggota keluarganya (BBC, 2011).

Jatuhnya Ben Ali yang telah memerintah Tunisia selama lebih dari 20 tahun menyebarkan euforia ke berbagai warga Timur Tengah. Tercatat warga di Mesir, Yaman, Suriah, dan Bahrain melakukan hal serupa, pun dengan Libya. Kasus Libya menjadi menarik karena pemimpin negara tersebut Muammar Qaddafi bersikeras tidak akan mundur dari kekuasaannya. Qaddafi memilih menggunakan kekerasan untuk melawan tuntutan para demonstran. Tercatat pada demonstrasi anti pemerintah yang diselenggarakan di Benghazi dan Tripoli pada bulan Februari 2011, terdapat korban jiwa dari pihak demonstran (CNN, 2014).

Sikap keras Qaddafi pada demonstran tidak menyurutkan tuntutan mereka. Berbekal dukungan dari sejumlah aparat militer dan pejabat yang membelot, sebagian warga memilih mengubah aksi mereka ke dalam bentuk perlawanan bersenjata. Secara formal, kekuatan anti Qaddafi ini diresmikan dengan membentuk National Transitional Council (NTC) di Benghazi yang merupakan basis massa anti Qaddafi. NTC sendiri dipimpin oleh Mahmoud Jibril, seorang lulusan Barat yang sempat menjabat sebagai kepala National Economic Development Board (NEDB) di era Qaddafi. Tugas lembaga yang dikepalainya sendiri terkait dengan upaya mengundang investasi asing di Libya (BBC, 2012).

Pendirian NTC menandai era baru aksi anti pemerintah di Libya yang berubah 
menjadi perang saudara antara pemberontak anti Qaddafi dan pasukan pro Qaddafi. Pertempuran yang terjadi antara pasukan pro Qaddafi dan anti Qaddafi berlangsung di sejumlah wilayah. Akan tetapi, bulan Maret 2011 seakan menjadi titik balik perang saudara ketika pasukan Qaddafi berhasil memperoleh sejumlah kemenangan di kotakota yang sebelumnya dikuasai oleh pasukan anti Qaddadi.

Dua kota yang seiring disebut sebagai titik balik pertempuran ialah kota Zuwarah dan Ajdabiya yang merupakan kota penting yang sebelumnya berada di bawah kendali pasukan anti Qaddafi. Untuk merebut kota Zuwarah, tidak memakan waktu lama, hanya membutuhkan sekitar beberapa jam saja. Kemenangan gemilang pasukan pro Qaddafi tidak dapat dilepaskan dari strategi pengepungan kota dan persenjataan yang memadahi (Al Jazeera, 2011). Kota Ajdabiya sendiri membutuhkan tenaga ekstra untuk menguasainya. Menurut saksi mata di kota tersebut, pasukan Qaddafi melakukan serangan udara setiap 20 menit (Al Jazeera, 2011a).

Kemenangan tersebut membuat Qaddafi membuat keputusan menawarkan amnesti pada pasukan anti Qaddafi; Bahwa siapa saja yang meletakkan senjatanya akan diampuni (The Guardian, 2011). Pernyataan Qaddafi tersebut secara tidak langsung menyiratkan terdesaknya pertahanan pasukan anti Qaddafi di berbagai wilayah. Terlebih lagi dengan penguasaan Ajdabiya memuluskan jalan pasukan pro Qaddafi ke Benghazi yang menjadi pusat pemberontakan dan merupakan markas NTC. Rob Crilly, kontributor The Telegraph (2011), mengambarkan situasi di Benghazi sangat mencekam paska jatuhnya Ajdabiya. Menurut Crilly, Benghazi hanya bisa berharap pada bantuan asing untuk menolong mereka. Crilly sendiri meyakini kejatuhan Benghazi tanpa pertolongan hanya menunggu waktu.

Merebaknya demonstrasi anti pemerintah yang kemudian bertransformasi menjadi perang saudara di Libya inilah yang menarik perhatian sebuah negara maju yakni AS. AS sendiri memiliki sejarah panjang kebencian terhadap pemerintahan Qaddafi.
Semenjak Qaddafi memegang tampuk kekuasaan di Libya di tahun 1969, AS sudah menunjukkan kebencian terhadapnya dikarenakan rezim yang memerintah Libya sebelumnya dikenal dekat dengan AS. Berbeda dengan pendahulunya, Qaddafi dikenal dengan sikapnya yang anti barat. Pertentangan dengan AS dan sejumlah negara barat lain memuncak setelah terjadinya sejumlah aksi terorisme yang diatributkan pada Qaddafi, seperti serangan Lockerbie di tahun 1988 yang menewaskan 189 warga AS. Selain serangan Lockerbie, Qaddafi juga dituduh mendanai Irish Republican Army (IRA) yang dinyatakan sebagai organisasi teroris oleh pemerintah Inggris. Qaddafi juga dituduh bertanggung jawab atas pemboman klub malam di Berlin, Jerman yang menewaskan 3 orang dan melukai 200 orang lainnya (Lansford, 2007: 115-116).

Sebagai balasan dari aksi yang dituduhkan pada Qaddafi tersebut, AS tercatat telah melakukan serangan bom pada Benghazi dan Tripoli, dan diperkirakan salah satu targetnya adalah kediaman Qaddafi (Esterhuysen, 2013: 241). Jelas dari sejarah permusuhan AS-Qaddafi ini, AS memandang terjadinya konflik saudara di Libya sebagai peluang emas menyingkirkan Qaddafi. Dalam hal ini keterlibatan AS dalam konflik Libya jelas tidak bisa dipahami semata-mata karena jeritan rakyat Libya, penderitaan rakyat Libya, atau sikap humanis AS. Tetapi ada kepentingan penyingkiran Qaddafi di balik keterlibatan AS.

Strategi AS untuk menjalankan kepentingan politik melalui misi perdamaian tidaklah sulit. Sebelumnya dunia internasional sudah mencermati konflik di Libya dan menghimbau agar konflik yang terjadi dapat segera diselesaikan. PBB sebagai lembaga yang memiliki legitimasi kuat membentuk misi perdamaian sudah memberikan lampu kuning pada Qaddafi. Tercatat pada tanggal 26 Februari 2011 Dewan Keamanan PBB mengeluarkan resolusi yang isinya memberlakukan embargo senjata atas Libya karena pelanggaran HAM yang dilakukan pemerintahan Qaddafi pada demonstran di negara tersebut (Sipri, 2014). 
Keluarnya resolusi dewan keamanan tidaklah sulit sebab posisi AS dan sekutunya dalam Dewan Keamanan PBB terbilang kuat. Namun resolusi tersebut tidaklah cukup karena tujuan AS ialah penggulingan rezim Qaddafi. Tercatat pada tanggal 10 Maret 2011 AS mengumpulkan negara sekutunya dalam NATO untuk menciptakan no-fly zone (zona larangan terbang) di wilayah Libya dengan alasan melindungi warga dari serangan udara tentara Qaddafi (CNN, 2014).

Terdesaknya pasukan pemberontak dari tentara pro Qaddafi di sejumlah kota, dan terjadinya pengepungan ibukota kaum anti Qaddafi di Benghzai menjadi lampu hijau bagi AS untuk membawa ide no-fly zone ke dalam sidang Dewan Keamanan PBB. Tanpa diduga sidang tersebut berjalan lancar dengan menyisakan sejumlah negara yang notabene dekat dengan Qaddafi seperti Russia dan China abstain (International Business Times, 2011).

Abstainnya Russia dan China tidak dapat dilepaskan dari kepiawaian pendukung no-fly zone yang dikomandoi AS untuk menyusun kata-kata. Ditegaskan bahwa resolusi memberikan mandat untuk membuat no-fly zone, termasuk melaksanakan segala upaya yang diperlukan untuk melindungi rakyat Libya, termasuk Benghazi. Akan tetapi, misi ini tidak diperkenankan untuk mendirikan tentara pendudukan (International Business Times, 2011). Klausul tiada tentara pendudukan inilah yang nampaknya meluluhkan hati Tiongkok dan Russia untuk tidak bersikap menolak resolusi tersebut.

Permainan kata-kata tersebut sudah tercemin dari penegsan Clinton yang menyatakan pendirian no-fly zone tidak dapat dilepaskan dari perlunya melakukan serangan udara pada instalasi pertahanan udara Libya agar dapat melindungi pilot dan pesawat yang melakukan tugasnya mempertahankan no-fly zone (International Business Times, 2011). Ucapan Clinton sejatinya menyiratkan makna bahwa no-fly zone yang dimaksud AS ialah no-fly zone "plus", dimana serangan terhadap instalasi militer yang dianggap ancaman bagi keberadaan no-fly zone dimusnahkan
Lebih jauh area no-fly zone yang dibayangkan AS ternyata sangatlah luas. Pada hakikatnya no-fly zone mencakup hampir seluruh Libya. Padahal wilayah yang dikuasai pemberontak atau yang merupakan basis bagi kalangan anti Qaddafi relatif hanya di wilayah Laut Mediterania saja. Ruang lingkup no-fly zone yang sangat besar menjadi pertanyaan tersendiri. Benarkah itu hanya untuk melindungi rakyat yang terzalimi atau supaya tentara asing leluasa menerobos masuk wilayah kedaulatan Libya guna menyingkirkan Qaddafi?

Ruang gerak AS dalam misi Libya semakin luas jika mencermati adanya klausul dalam resolusi Dewan Keamanan PBB yang memperbolehkan dilakukannya segala tindakan untuk "melindungi warga Libya" (Schütte, 2011:2). Klausul tersebut dapat diartikan sebagai lampu hijau untuk menghancurkan rezim Qaddafi yang dianggap sebagai ancaman bagi keamanan warga Libya.

Dengan adanya lampu hijau lewat resolusi Dewan Keamanan tersebut, AS dapat melancarkan aksi militer ke Libya secara bebas di bawah payung misi perdamaian. Dengan payung aksi perdamaian, AS juga mendapatkan bantuan militer dari sejumlah negara sekutu AS seperti Perancis dan Inggris. Tercatat dalam upaya penerapan no-fly zone dan "perlindungan terhadap warga Libya", Perancis melancarkan serangan udaranya untuk menghancurkan kendaraan militer pasukan pro Qaddafi yang mengelilingi Benghazi. Serangan tersebut disusul dengan serangan misil Tomahawk AS yang diperkirakan berjumlah 110 buah untuk mengantam pertahanan udara Qaddafi di Tripoli dan Misrata (NBCnews, 2011)

Aksi yang nampaknya menegakkan misi kemanusiaan tersebut semakin terlihat keanehannya di kemudian hari. Jika alasannya ialah mencegah serangan Qaddafi pada penduduk sipil sekaligus memastikan berjalannya no-fly zone, mengapa pasukan perdamaian tersebut menutup mata terhadap sinyal yang diberikan Qaddafi untuk melakukan gencatan senjata? Qaddafi sendiri mengumumkan gencatan senjata melalui televisi nasional Libya pada tanggal 30 April 2011 (BBC, 2014). Akan tetapi tidak terlihat 
inisiatif dari tentara perdamaian di bawah pimpinan AS untuk merespon positif seruan Qaddafi tersbebut dan berupaya mempertemukan kedua belah pihak yang bertikai.

Lebih jauh, ketika muncul usulan yang ditawarkan oleh Uni Afrika pada bulan yang sama (April 2011) mengenai konsep peta jalan damai kepada NTC dan Qaddafi, tidak ada tanggapan dari pasukan perdamaian di bawah pimpinan AS. Padahal peta jalan damai tersebut memuat poin-poin menarik seperti gencatan senjata kedua belah pihak, pengiriman bantuan kemanusiaan untuk warga sipil, dan dialog kedua belah pihak agar tercapai kesepakatan tertentu yang dapat diterima semua kalangan (Al Jazeera, 2011b).

Uni Afrika sendiri telah mencoba secara langsung berhubungan dengan kedua pihak yang bertikai, yakni Qaddafi dan NTC. Upaya Uni Afrika mengupayakan solusi damai ditolak mentah-mentah oleh NTC. NTC beralasan peta jalan damai tersebut sudah usang, dan tidak layak diterapkan dalam keadaan Libya terkini (Al Jazeera, 2011b). Penolakan NTC mungkin dapat dipahami karena sebagai kubu yang bertikai, NTC terlanjur dendam pada Qaddafi. Akan tetapi yang mengherankan tidak ada upaya dari pasukan perdamaian untuk "memaksa" NTC agar menerima proposal tersebut, padahal sinyal positif telah diberikan oleh rezim Qaddafi dengan menyetujui usulan Uni Afrika tersebut.

Sikap pasukan perdamaian AS yang enggan mendudukkan dua belah pihak yang bertikai, ditambah tidak adanya sinyal penghentian serangan pasukan perdamaian ke kubu Qaddafi, menunjukkan bahwa tujuan utama pasukan perdamaian bukanlah terkait penciptaan kondisi agar masyarakat Libya bebas dari konflik, tetapi penyingkiran Qaddafi apapun resikonya, bahkan jika jatuhnya korban dari kalangan sipil semakin besar akibat perang yang terus terjadi.

Ketika misi perdamaian yang pada hakikatnya hanya dilaksanakan untuk memenuhi kepentingan AS guna menjatuhkan Qaddafi, terlihat nyata dampaknya ketika pada akhirnya Qaddafi berhasil terbunuh. Kondisi Libya paska rezim Qaddafi dapat dikatakan tidaklah lebih baik dan cenderung carut marut. Hal ini tidak dapat dilepaskan dari vakumnya kekuasaan Libya pasca Qaddafi dan terjadinya perebutan pengaruh antar kelompok yang dahulu bersatu ketika melawan Qaddafi.

Sejatinya jika solusi yang ditawarkan Uni Afrika dijalankan, maka transisi kekuasaan akan lebih mulus didahului oleh upaya dialog pihak-pihak yang bertikai khususnya pihak pro Qaddafi dan pihak anti Qaddafi. Pada masa dialog itulah warga dapat bernafas dengan lega dan dapat memperoleh bantuan kemanusiaan yang layak untuk memulai kehidupannya kembali. Akan tetapi dengan adanya perebutan kekuasaan yang terjadi hingga saat ini, ditambah lepas tangannya AS yang dahulu "terdepan" dalam melakukan "misi kemanusiaan" di Libya menjadikan kondisi Libya tidak menentu. Dapat dikatakan misi perdamaian AS dalam konflik Libya bukan menghapus konflik tetapi menciptakan konflik baru. Hal ini merupakan sebuah ironi besar dari sebuah tindakan yang mengatasnamakan perdamaian dan perlindungan terhadap warga sipil.

\section{Kesimpulan}

Berdasarkan pemaparan diatas dapat ditarik kesimpulan bahwa eksistensi misi perdamaian tidaklah selalu seindah yang dibayangkan. Hal ini dapat terjadi dikarenakan merasuknya kepentingan-kepentingan lain yang dapat mengganggu terwujudnya idealisme dari misi perdamaian itu sendiri yang berbasis pada nilai kemanusiaaan, imparsialitas, netralitas, dan mengutamakan dialog.

Poin penting yang dapat ditarik dari pemaparan diatas ialah perlunya sikap kritis dalam menilai sebuah operasi perdamaian. Dengan ini seorang akan lebih jeli dalam mencermati sebuah misi perdamaian, apakah ia sudah melenceng dari "khittahnya" atau tidak. Sebagaimana seseorang akademisi yang tidak tertipu pada label yang dipakai sebuah negara yang mengklaim demokrasi seperti Korea Utara, yang memiliki nama resmi Democratic People's Republic of Korea namun pada hakikatnya tidak demokratis, maka seyogyanya ia lebih jeli untuk mencermati fenomena lain yang memakai 
label yang seakan terlihat indah, seperti misi perdamaian ini.

Poin lain yang dapat dipetik dari pembahasan diatas ialah pentingnya memandang misi perdamaian dalam tataran konsep dalam dunia ilmiah sebagai sesuatu yang tidak netral kuasa. Bahkan, dapat dikatakan konsep misi perdamaian merupakan strategi baru intervensi negara maju kepada negara berkembang berkedok kemanusiaan dan perdamaian. Tidak salah jika dikatakan konsep misi perdamaian, ,jika dibiarkan tanpa kritik, dapat disebut sebagai strategi neo civilizing mission dari negaranegara maju. Negara-negara maju dapat melakukan intervensi kepada negara dunia ketiga demi kepentingan mereka, namun negara dunia ketiga atau masyarakat dunia secara umum justru memandang intervensi tersebut sebagai kebaikan guna menciptakan kedamaian dan mengakhiri konflik yang terjadi di sebuah negara.

Maka langkah yang harus diambil, khususnya oleh akademisi dan pengambil kebijakan di negara dunia ketiga, ialah aktif dalam memberi makna pada konsep misi perdamaian tersebut. Karena jika konsep tersebut dibiarkan tanpa adanya kritik lebih lanjut, hal ini dapat menjadi celah yang dapat digunakan negara-negara maju seperti AS untuk menggunakannya demi kepentingannya sendiri. Diharapkan dengan sikap kritis dan upaya aktif untuk ikut mendefinisikan konsep misi perdamaian, tatanan dunia damai yang dibayangkan konsepsi tersebut secara ideal dapat tercapai tanpa ditunggangi atau dibajak oleh kepentingan politik negara tertentu.

\section{Daftar Pustaka}

\section{Buku}

Abrahamsen, R. (2000) Sudut Gelap Kemajuan. Yogyakarta: Lafadl Pustaka.

Alex J. Bellamy, P.W. (2010) Understanding Peacekeeping. $2^{\text {nd }}$ edition. Cambridge: Polity Press.

Esterhuysen, P. (ed.) (2013) Africa A to Z: Continental and Country Profiles. $3^{\text {rd }}$ edition. Pretoria: Africa Institute of South Africa.
Headquarters of the Armed Forces of the Republic of Indonesia. (1995) ABRI: Patriot \& Soldier. Jakarta: PT Wikson Perkasa.

Lansford, T. (2007) Historical Dictionary of U.S. Diplomacy since the Cold War. Plymouth: Scarecrow Press.

Renner, M. (1995) 'Misi Perdamaian PBB Meningkat', in Lester R Brown, H.K.E.A. Tanda Tanda Zaman Era 90-an, Jakarta: Yayasan Obor Indonesia.

Said, E. (1994) Culture and Imperialism. New York: Vintage Books.

Schütte, R. (2011) Minding the Gap: Approaches and Challenges to Robust Civilian Protection. New York: The Friedrich-Ebert-Stiftung.

Yulianto, M.A. (2010) Lebanon Pra- Dan Pasca-Perang 34 Hari Israel VS Hizbullah. Jakarta: PT Gramedia Pustaka Utama.

\section{Jurnal}

UNESCAP (no date) What is Good Governance?. Bangkok: United Nations Economic and Social Commission for Asia and the Pacific.

\section{Majalah}

Warta Akrab. $73^{\text {rd }}$ edition (2009). Jakarta: Batanawarsa.

\section{Tesis}

Ross, M. (2011) A Regime Legitimacy Explanation of African Peacekeeping, Tesis. California: Naval Postgraduate School.

\section{Artikel dalam Jaringan}

Al Jazeera. (2011a) Gaddafi forces make gains. [Online]. Available from: http://www.aljazeera.com/news/africa/2 011/03/201131420334113181.html [Accessed 20 Oktober 2014].

Al Jazeera. (2011b) Libyan rebels reject African Union road map [Online]. Available from: http://www.aljazee ra.com/news/africa/2011/04/2011411163 56323979.html [Accesed 20 Oktober 2014]. 
BBC. (2011) Tunisia: President Zine alAbidine Ben Ali forced out [Online]. Available from: http://www.bbc.co.uk/news/worldafrica-12195025 [Accesed 20 Oktober 2014]

BBC. (2012) Profile: Mahmoud Jibril, [Online]. Available from: http://www. bbc.com/news/world-africa-18838990 [Accesed 20 Oktober 2014].

BBC Indonesia. (2005) Indonesia: tentara asing harus dibatasi [Online]. Available from: http://www.bbc.co.uk/indonesian/news/ story/2005/01/050114_aceh.shtml [Accesed 19 Oktober 2014].

CNN. (2014) Libya Civil War Fast Facts [Online]. Available from: http://edition. cnn.com/2013/o9/20/world/libya-civilwar-fast-facts/ [Accesed 20 Oktober 2014].

Daily Mail. (2011) 'Terms are not negotiable': Obama stands firm against Gaddafi as U.S. sends extra ships to police no-fly zone [Online]. Available from: http://www.dailymail.co.uk/news/article -1367357/Libya-protests-World-backsair-strikes-Gadaffi-UN-votes-protectrebels.html [Accesed 20 Oktober 2014].

Gosh, T. (2010) The motivations behind African peacekeeping contributions [Online]. Available from: http://panos. org.uk/features/the-motivations-behindafrican-peacekeeping-contributions/ [Accesed 19 Oktober 2014].

International Business Times. (2011) UN Vote Approves Libya No-Fly Zone; China, Russia Abstain [Online]. Available from: http://www.ibtimes.com/un-vote-appro ves-libya-no-fly-zone-china-russiaabstain-276107 [Accesed 20 Oktober 2014].

Jackson, R.J. (1997) NATO AND PEACEKEEPING [Online]. Available: http://www.nato.int/acad/fellow/95-97/ jackson.pdf.

NATO. (2012) Peace support operations in Bosnia and Herzegovina [Online]. Available from: http://www.nato.int/ cps/en/natolive/topics_52122.htm [Accesed 19 Oktober 2014].
NBC News. (2011) gadafi blast 'Crusader' agression after strikes [Online]. Available from: http://www.nbcnews. com/id/42164455/ns/world_newsmideastn_africa\#.VEnGRCKsVuA [Accesed 20 Oktober 2014].

Said, E. (1993) Culture and Imperialism [Online] Toronto: York University. Available from: http://engres.ied.edu. hk/literature/E-lecture(Mat)/Week3(Ru dyardKipling)/Culture\%20and\%20Imper ialism.pdf.

Sipri. (2014) UN Arms embargo on Libya [Online]. Available from: http://www.sipri.org/databases/embarg oes/un_arms_embargoes/libya/libya_2 011/un-arms-embargo-on-libya-2011-pdf [Accesed 20 Oktober 2014].

The Guardian. (2011) Muammar Gaddafi offers rebels an amnesty [Online]. Available from: http://www.theguardian. com/world/2011/mar/o2/muammargaddafi-offers-rebels-amnesty [Accesed 20 Oktober 2014].

The New York Times. (2011a) How a Single Match Can Ignite a Revolution [Online]. Available from: http://www.nytimes. com/2011/01/23/weekinreview/23worth .$h t m l$ ssc $=$ twrhp\&_r $=0 \quad$ [Accesed 20 Oktober 2014].

The New York Times. (2011b) Map of the Rebellion in Libya, Day by Day [Online]. Available from: http://www.nytimes. com/interactive/2011/02/25/world/mid dleeast/map-of-how-the-protestsunfolded-in-libya.html [Accesed 20 Oktober 2014].

The Telegraph. (2011) Libya: Benghazi about to fall. then came the planes [Online]. Available from: http://www.telegraph. co.uk/news/worldnews/africaandindiano cean/libya/8393843/Libya-Benghaziabout-to-fall.-then-came-the-planes.html [Accesed 20 Oktober 2014].

Urlacher, B. (2008) Answering the Call: A mid-range theory of major contributions to UN peacekeeping missions [Online]. Available from: http://www.academia. edu/2524036/Contributions_to_UN_Pe acekeeping_Operations_Who_and_Why [Accesed 15 Oktober 2014]. 
US Departement of Defence.WALL OF WATER U.S. Troops Aid Tsunami Victims [Online]. Available from: http://www.defense.gov/home/features/ 2006/2005yearinreview/article2.html [Accesed 19 Oktober 2014]. 